Abant Tıp Dergisi

Olgu Sunumu / Cilt 10 Sayı 1 YII 2021
Abant Medical Journal

Case Report / Volume 10 Issue 1 Year 2021

\title{
Gözden Kaçan Olgularda Kedi Tırmığı Hastalığı
}

Cat Scratch Disease in Unnoticed Cases

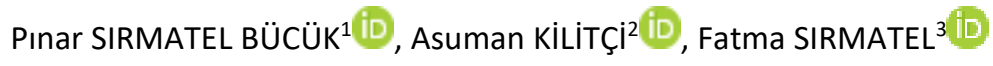

${ }^{1}$ Ege Üniversitesi Tıp Fakültesi, İç Hastalıkları, Geriatri Bilim Dalı, İzmir, Türkiye

${ }^{2}$ Ahi Evran Üniversitesi Tıp Fakültesi, Patoloji Anabilim Dalı, Kırşehir, Türkiye

${ }^{3}$ Bolu Abant İzzet Baysal Üniversitesi Tıp Fakültesi, Enfeksiyon Hastalıkları, Bolu, Türkiye

\section{Öz}

Kedi tırmığı hastalığı ülkemizde olgular şeklinde bildirilen, insanlara hayvanlardan bulaşan bir zoonozdur. Illk olgumuz iki yıl önce kadranektomi ve sentinel lenf nodu diseksiyonu sonrası, sol memede invaziv meduller karsinom tanısı alan 62 yaşında bir bayan hasta. Rutin takiplerinde tekrarlayan aksiller kitle saptanınca, alınan biyopsi materyalinde kedi tırmı hastalığı tanısı konuldu. İkinci olgu altı aydan beri nedeni bilinmeyen ateş ve aksiller lenfadenopati ile izlenen bir erkek hasta. ikinci olgunun tanısı serolojik olarak konuldu. Kliniğimizde izlediğimiz iki kedi tırmığı hastalığı vakalarını sunarak hastalığın tanısında klinik, histopatolojik ve serolojik verilerin önemini vurgulamak istedik.

Anahtar Kelimeler: Meme kanseri; koltuk altı lenfadenopati; kedi tırmığı hastalığı

\section{GíRiş}

Kedi Tırmığı Hastalığı (KTH) daha ziyade küçük kedilerden insanlara bulaşan kendi kendini sınırlayan bir zoonotik hastalıktır [1]. Bu hastalı̆ın etkeni Bartonella henselae (B. henselae) gram negatif bir basildir ve insanlara yakın temas, ısırılma, ve tırmalama ile bulaşır. Bakterinin girdiği ilk yerde 3-10 gün içinde gelişen eritematöz papül ve sonra bölgesel lenfadenopati (LAP) görülür. Hastaların halsizlik, ateş, kas ağrısı, baş ağrısı, bulantı, kusma gibi spesifik olmayan şikayetlerinin yanı sıra en önemli bulgusu, bölgesel LAP ile görülmesidir [2]. Bazen nedeni bilinmeyen ateş, zayıflama, aşırı yorgunluk, LAP'nin değişik bölgelerde olması, nadiren kadınlarda aksiller bölgede LAP saptanması ve

\section{Abstract}

Cat scratch disease is a zoonotic disease which is transmitted from animals to people reported as cases in our country. The first case was a 62 -year-old female patient who had been diagnosed as invasive medullary carcinoma in the left breast mass with a quadrantectomy and sentinel lymph node dissection two years ago. When recurrent axillary mass was detected during routine follow-up, biopsy revealed cat scratch disease. Our second case was a men who had followed up unknown origin fever and axillary lymphadenopathy for two months. Second case was confirmed by seropositivity. We present two cases of cat scratch disease in our clinic and emphasize the importance of clinical, histopathological and serological data in the diagnosis of the disease.

Keywords: Breast cancer; axillary lymhatic nodes; cat scratch disease

yanlışlıkla klinik olarak, malignite ile karıştırımasına yol açabilir [3-5]. Bakterinin yaptığı hastalığın tanısı, klinik örneklerden bakterinin izolasyonu, genetik materyalinin gösterilmesi, serolojik ve histopatolojik inceleme ile konulur [6,7]. Bakterinin bulunması, dokuda histolojik boyalarla (direk), ya da hasta serumunda B. henselae'ya karşı özgül antikorların gösterilmesiyle (indirek) doğrulanır $[6,8,9]$

Bu yazıda iki farklı klinik tabloda kedi tırmı ı hastalığı olgusu sunuldu.

Olgu 1: 63 yaşında kadın hasta, sol koltuk altında tekrarlayan LAP ve halsizlik yakınması ile başvurdu. Hastanın öyküsünde on beş yıldan beri sigara (günde $1 / 2$ paket), üç yıldır antihipertansif ilaç kullanımı vardı. íki yıl önce rutin kontrol 
sırasında sol memede kitle saptanması üzerine hastaya; kadranektomi ve sentinel lenf nodu diseksiyonu yapılmış, histolojik olarak invaziv meduller karsinom tanısı konulmuştu. Hastanın tanımlamasına göre, zaman zaman sol koltuk altında tekrarlayan LAP durumu enfeksiyona bağlı olarak değerlendirilmiş ve farklı antibiyotikler kullanmış. Bu zaman sürecinde yapılan ultrasonografide koltuk altında birden fazla 0.6$12 \mathrm{~mm}$ boyutlarında yaygın LAP 'ler saptanınca, genel cerrahi uzmanı tarafından nüks şüphesiyle lenf biyopsisi yapılmış. Tanı amaçlı yapılan eksizyonel lenf nodu biyopsisinde "Abseleşen Akut Nekrotizan Lenfadenit" olarak rapor edilince (Resim 1 ve 2) genel cerrahın önerisi ve hastanın kendi isteğiyle tamamlayıcı mastektomi ve sol aksiler diseksiyon yapılarak alınan materyallerin hepsi patolojiye tekrar gönderilmiş. Yapılan incelemede histopatolojik olarak disseke edilen 22 adet lenf nodlarının tamamının kesitlerinde bir kısmı fibrinoid materyal ve nötrofilik debris içeren epiteloid histiyositlerin oluşturduğu birbiriyle birleşme eğiliminde olan granülomatöz lenfadenit bulguları gözlenmiş. Histopatolojik olarak granülom yapılarına, fokal bir-iki alanda dev hücreler eşlik ettiği ve meme kadranlarından hazırlanan kesitlerde özellik görülmemiş. Hasta patolojik olarak morfolojik bulgular eşliğinde "KTH ile uyumlu non-kazeifiye granülomatöz lenfadenit" olarak değerlendirilmiş ve sonra enfeksiyon hastalıkları kliniğine yönlendirilmiştir. Hastanın preoperatif ve postoperatif izleminde yapılan rutin tam kan, sedim, CRP ve kan biyokimyasal testleri normal bulundu. Hastanın derin sorgulamasında 2 yıldan beri evinde kedi beslediği öğrenildi. Ayırıcı tanıda diğer olası granülamötöz hastalıklar (tüberküloz, bruselloz, sarkoidoz, toksoplazmozis ve mantar hastalıkları) serolojik, mikrobiyolojik ve histolojik olarak dışlandı. KTH için yapılan kan serolojisi negatif bulunmasına rağmen hasta iki aylık doksisiklin (200 mgr/gün) tedavisine alındı. Hastanın koltuk altında bulunan LAP ve halsizlik yakınması tümüyle kayboldu ve takiplerinde tekrarlama olmadı.

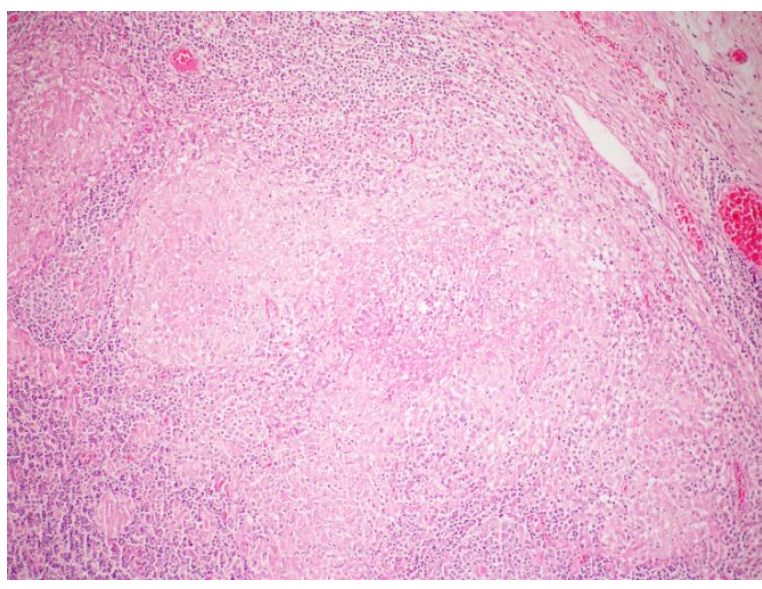

Resim 1. Aksiller lenf nodu kesitlerinde, nekroz alanlarını çevreleyen yoğun histiyosit, lenfosit, daha az olarak da polimorf nüveli lökosit infiltrasyonu görülmektedir (H\&E, $\mathrm{X} 100)$.

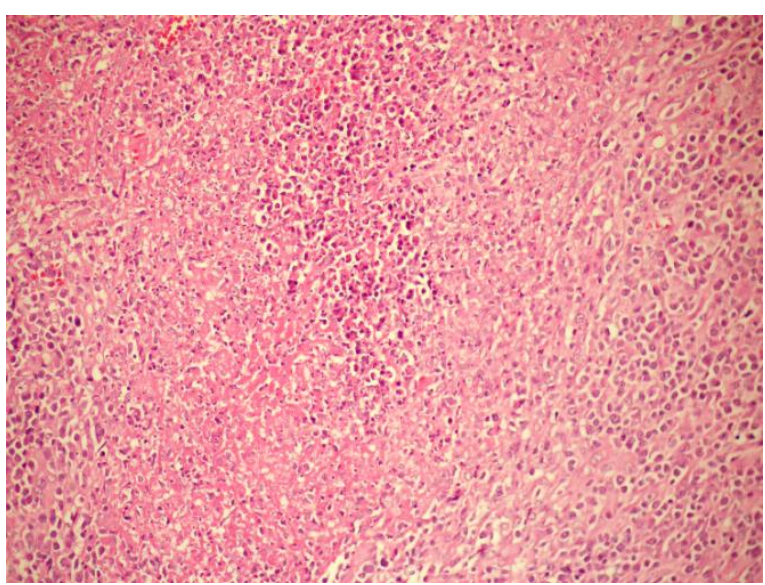

Resim 2. Büyük büyütmede; granülomların ortasında nötrofiller ve çevrelerinde histiyosit ve lenfositler gözleniyor (H\&E, X200).

Olgu 2: 62 yaşında emekli erkek hasta 6 aydan beri zayıflama, halsizlik. ateş şikayeti ile değişik poliklinikler tarafından izlenmiş. Hastanın nedeni bilinmeyen ateş nedeni ile polikliniğimize geldiği zaman sol koltuk altında hafif ağrılı ve hassas ( $4 \times 2$ cm çapında hareketli) LAP dışında bir patolojik bulgusu yoktu. Hastanın LAP ve ateş nedeni ile etiyolojiye yönelik yapılan laboratuar tetkiklerinde (genis biyokimya, hemogram, akut faz tetkıklerı, TiT, gaitada gizli kan, PSA) bir patoloji saptanmadı. Aksiller LAP nedeni ile yapılan serolojik incelemesinde (CMV Ig G, EBV VCA Ig $G$ ve EBV EBNA pozitif) geçirilmiş viral enfeksiyonlar dışında başka bir anormal seropozitiflik saptanmadı. Hasta aksiler LAP biyopsisini kabul etmedi. Ayrıntılı öyküsünde kedilerle teması olunca Sağlık Bakanlığı Halk 
Sağlığı Laboratuvarı-Ankara'da enzim immuno assay (EIA) yöntemiyle Bartonella henselae antikor pozitifliği $1 / 256$ da pozitif bulundu. Hastaya 8 hafta doksisiklin (2x100 mgr/gün oral) tedavisi verildikten sonra, tüm şikayetleri ve (4 ay sonra) aksiller LAP'si tamamen kayboldu.

\section{TARTIŞMA VE SONUÇ:}

Kedi tırmığı hastalığı, sıklıkla sporadik olgular şeklinde olmakla birlikte, aile içi ve küçük epidemiler şeklinde de görülebilir $[1,7]$. Ülkemizden de olgular şeklinde KTH ve basiller anjiyomatozis tabloları bildirilmiştir $[1,4,7]$. Kedi tırmığı hastalığı tipik ve atipik form olmak üzere iki şekilde gelişir. Tipik formda tırmalama veya ısırma yerinde 3-12 gün içinde 2-10 mm çapında ağrısız eritematöz papül veya püstül şeklinde, bir primer lezyon ortaya çıkar ve genellikle iz bırakmadan 2-4 hafta içinde iyileşir. Hastalığın, bulaşı takiben gelişen bölgesel LAP'si en önemli klinik belirtidir. Lenfadenopati genellikle 2-4 ay kadar devam ederse de bazı olgularda daha uzun süre kalabilir. Olguların \%10-30'nda lenf bezlerinde süpürasyon gelişirken, nadiren yaygın LAP de görülebilir $[1,6]$. İmmün kompetan bireylerde KTH spontan olarak 2-5 ay içerisinde genelde sekel bırakmadan iyileşir. Ancak immun sistemin baskılandığı (AIDS, malignite, kortizon ve immün süpresif ajan kullananlarda) durumlarda yaygın LAP yaşamı tehdit eden klinik tablolara dönüşebilir $[8,9]$. Son yıllarda etkenle temas eden olguların \%10-25'inde KTH'nın atipik formunun geliştiği bildirilmiştir [1,6]. Atipik form, uzun süreli ateş, okülo-glandüler sendrom (\%56), steomiyelit (\%0-3), pnömoni (\%0-2), nörolojik (\%1-7) semptomlar, granülomatöz hepatit ve değişik organ tutulumları (endokardit, ensefalit, artrit, sinovit) şeklinde görülebilir $[5,6,10]$.

Kedi tırmığı hastalığının en önemli ve bazen tek bulgusu olan LAP bir çok klinik tablo ile karışabilir. Bu durum malignite (lenfoma, metastatik lenfofaringeal kanser, meme kanserleri), bir çok enfeksiyon hastalığı (tüberküloz, veba, toksoplazmoz, tularemi, histoplazmoz, lenfo- granüloma venorum, sifiliz, bruselloz vb.) ve sarkoidoz ile karıştırılabilir. Hastalık bölgesel LAP yanı sıra ateş, halsizlik, yorgunluk ve zayıflama gibi yakınmalarla atipik olarak kendini gösterir. Sunulan ilk olguda LAP ve halsizlik dışında başka bir bulgu görülmez iken ikinci olguda LAP yanında ateş, halsizlik zayıflama gibi spesifik olmayan şikayetler vardı. Her iki olguda atipik forma uyuyordu.

Illk defa Lefkowitz ve arkadaşları [13] dört olguda memede soliter kitle olarak KTH 'nı tanımlamışlardır. Kedi tırmı̆̆ı hastalığı olguları ülkemizden tipik/atipik olgular şeklinde bildirilirken çoğunlukla vücudun değişik bölgelerinde LAP olarak da sunulmuştur $[4,7,11]$. Böyük ve arkadaşları [4] 44 yaşında, bir bayan hastanın koltuk altında gelişen LAP'ni, bizimkine benzer şekilde ön planda meme malignitesi olabileceğini düşünmüşler ve yapılan biyopsi sonucu KTH olarak tanımlayıp tedavi etmişlerdir. Literatürde memede öncelikle malign kitle olarak düşünülüp histopatolojik inceleme sonrasında KTH tanısı alan az sayıda olgu bildirilmiştir $[3,6]$. lannace ve ark. [3] sunduğu bir olguda, sağ memede kitlesi ve koltuk altında LAP olan bir olgunun KTH tanısını patolojik olarak koymuşlardır. Bu derlemede memede nadir görülen kitlenin KTH olmasına dikkat çekerek aşağıda belirtilen beş kriterden üçünü gösteren LAP olgularında KTH düşünülmesini önermekteyiz. Yapılan bir derlemede aşağıdaki kriterlere göre KTH değerlendirmek gerekir.

Bunlar:

1. Hastanın kedilerle teması, 2. Bölgesel LAP olması, 3. Kültür ve serolojik olarak LAP yapacak olguların dışlanması, 4. cilt testinin pozitif olması, 5. histolojik olarak spesifik KTH bulgularının bulunmasıdır. Ayrıca görüntüleme yöntemleriyle (magnetik rezonans, ultrasonografi ve mamografi) malign kitle olarak değerlendirilen ancak histopatolojik tanısı KTH olan lezyonlara dikkat çekilmişdir [3].

Bizim ilk olgumuz meme kanseri açısından 
mamografiyle belli aralıklarla takip edilen bir hasta olup iki yıl önce meduller meme kanseri nedeni ile operasyon geçiren immunsüpressif bir hastadadır. Hastanın kedi ile temasından sonra gelişen LAP ve halsizliği başlangıçta dikkatten kaçmış ve olguda metastaz şüphesi doğurmuştur. Hastanın hastaneye başvurması sonucu yapılan histopatolojik incelemesi ile KTH olduğu doğrulanmıştır. i̇kinci olgunun koltuk altı LAP bulunması ve uzun süren ateşi malignite nedeni bilinmeyen ateş olarak araştırılmıştır. Ülkemizden bildirilen toplam $18 \mathrm{KTH}$ olgusunun sadece birinde nedeni bilinmeyen ateş ve LAP saptanmıştır [7]. Sunulan her iki olguda KTH için beş kriterden üçünü karşılamaktadır.

Kedi tırmığı hastalığı şüphesinde rutin laboratuvar testleri tanıya yardımcı değildir. Olguların tam kan analizinde sıklıkla hafif lökositoz ve sedimentasyon yüksekliği izlenebilir. Hastalığın tanısı, mikroorganizmanın dokuda direk veya kanda indirek-antikorlarının gösterilmesi ile konulur. İndirek tanı yöntemi olarak enzim immunoassay (EIA), floresan antikor testi (IFAT) kullanılırken bakteriye özgü polimeraz zincir reaksiyonu (PCR) kesin tanıyı gösterir [8]. Kedi tırmığı hastalığında LAP'nin histopatolojik incelemesinde, epiteloid, eozinofil ve dev hücrelerin çevrelediği merkezi nekrozlu çok sayıda uydu abselerin görülmesi karekteristiktir $[1,6]$. Brown-Hopp doku, Gram boyama ve Warthin-Starry gümüş boyama yöntemleriyle dokuda küçük, kıvrık, çomak şeklinde bakteriler görülebilir. Birinci olgumuzun tanısı histopatolojik olarak konulmuştur. İkinci olgumuzun şikayetleri, LAP ve anemnezi bize yol göstermiştir. Hastanın uzun süre değişik polikliniklerde incelenmesi LAP olasılığı olan nedenler dışlandıktan sonra serolojisinin pozitifliği ve tedaviye cevabı KTH tanısını desteklemektedir. íkinci olgumuzun KTH serolojisi Sağlık Bakanlığı Halk Sağlığı Laboratuvarı-Ankara'da EIA ile bakılmış ve 1/256 gibi yüksek gelmiştir. Akut safhada spesifik IgG titrasyonun $1 / 256$ olması KTH için kesin tanıdır $[1,6,7]$.
İmmün sistemi yeterli bireylerde, tipik hastalığın kendi kendini sınırlaması nedeniyle, antibiyotik tedavisinin uygulanması kesinlik kazanmamıştır. Tedavide ilk tercih olarak eritromisin veya doksisiklin kullanılır. Eğer başlangıç tedavisine 23 hafta içinde olumlu yanıt alınamazsa, azitromisin, ko-trimoksazol veya kinolonlar kullanılabilir. Ağır olgularda rifampin, gentamisin veya başka antibiyotikler kombine edilebilir. İkinci seçenek antibiyotikler ile tedavi süresinin 36 hafta olması önerilmektedir [1]. Bakteriyemik hastalar ise en az 4 hafta süreyle tedavi edilmelidir $[1,7,9]$. Her iki olgumuzda doksisiklin tedavisine cevap vermişlerdir. Illk hastamızın daha önceden birçok antibiyotik kullanması serolojisinin negatif olmasına neden olmuş olabilir. İlk olgumuzda olduğu gibi memede kitle ve LAP durumunda hastaların öyküleri dikkate alınmalıdır. Sunulan her iki olguda klinik olarak KTH olarak düşünülmüş ve birisi histolojik diğeri serolojik olarak doğrulanmıştır. O zamanki olanaklar doğrultusunda kültür ve PCR ile tanıyı doğrulayacak yöntemleri bulamadık. Olanaklarımız doğrultusunda alınan lenf biyopsi materyelinde moleküler olarak $B$. henseale saptayamadık. Ancak hastanın histolojik verileri ve anemnezi doğrultusunda antibiyotik tedavisi ile tedaviden tanıya gitmeyi tercih ettik. íkinci olguda derin anemnez ve seroloji bize yardımcı olmuştur. Ülkemizde olgular şeklinde bildirilen KTH son yıllarda artan HIV + olgularda ve immun süpressif tedavi gören hastalarda ve kültür negatif infektif endokarditlerde akla gelmelidir. Rutinde yapılmayan seroloji klinik olarak düşünülen olgularda yol gösterici olabilir. Gamblin ve ark. [12] serolojisi negatif olan 36 yaşında bir bayan hastada memede ve koltuk altında kitle incelemesinde ilk defa gümüşleme yöntemi ile alınan materyelde KTH etkeni olan basilleri göstermişlerdir. KTH immunsüpressif hastalarda daha belirgin bir klinik bulgu vermektedir. Nitekim Liston ve ark. [9] sol memede kitlesi olan eksizyonel biyopside invaziv duktal karsinom tanısı alan bir olgunun kemoterapiden bir yıl sonra gelişen ateş ve LAP 
bulgusunu yaygın KTH bağlamışlardır. Yazarlar bu olguda granülomatöz odakların karaciğer ve dalakta da yaygın olduğunu belirtmiş ve yapılan incelemede iç organ tutulumu olan 27 olgunun serolojisinin negatif ancak histopatolojik incelemesinin KTH için spesifik olduğunu rapor etmişlerdir.

Sunulan ilk olgumuzun enfeksiyon bulguları olmaksızın, görülen tekrarlayıcı aksiller LAP başlangıçta nospesifik antibiyotiklerle tedavi edilmiş ancak sonunda hastanın meme kanseri hikayesi ile ilişkilendirilerek öncelikle meme kanseri metastazı düşünülmesine ve bu açıdan tetkik edilmesine neden olmuştur. Eksizyonel biyopsi ve rezeksiyon materyalinin ilk histopatolojik incelemesi, tanıda malignitenin dışlanmasını sağlamasına rağmen malignite korkusu hekimi ve hastayı tedirgin etmiştir. Chondrogiannis ve ark. [8] bildirdiği gibi seronegatif immunsüpressif KTH olan olgular antibiyotik tedavisine iyi cevap verirler.

Sonuç olarak meme karsinomu tanısı olan kişilerde aksiller yerleşimli LAP'ler klinikte meme kanseri metastazıyla karışabilir. Bir başka açıdan nedeni izah edilemeyen ateş ve LAP olgularında KTH akla gelerek seroloji ile sonuç alınabilir. Kedilerle temas öyküsü olan ve belirgin olarak enfeksiyon bulgusu vermeyen aksiler LAP ile başvuran hastaların ayırıcı tanısında, nadir de olsa, KTH akla gelmelidir.

Bilgilendirilmiş Onam: Aileden sözlü onam alınmıştır.

Çıkar Çatışması: Yazarlar çıkar çatışması beyan etmemişlerdir.

Finansal Destek: Yazarlar finansal destek beyan etmemişlerdir.

\section{KAYNAKLAR}

1. Çelebi B.: Bartonella henselae and its infectıons. Mikrobiyol Bul 2008;163-175.

2. Korkmaz P., Naz H., Gücüyener MN., Çevik FÇ. AN: CatScratch Disease: A Case Report. 2015.

3. Iannace C, Lo Conte D, Di Libero L, Varricchio A, Testa $A$, Vigorito R, et al.: Cat Scratch Disease Presenting as
Breast Cancer: A Report of an Unusual Case. Case Rep Oncol Med 2013; 2013:1-4.

4. Böyük A, Üstün C, Solmaz ÖA, Altinsoy HB, Banli O: Meme Kanseri Đle Karışabilen Nadir Bir Olgu: Kedi Tırmığı Hastalı̆̆ı 2009;14:268-270.

5. Markaki S, Sotiropoulou M, Papaspirou P, Lazaris D: Cat-scratch disease presenting as a solitary tumour in the breast: Report of three cases. Eur J Obstet Gynecol Reprod Biol 2003; 106:175-178.

6. Klotz SA., lanas V. and ES: Cat-scratch Disease. Am Fam Physician 2011; 83:152-155.

7. Uluğ $\mathrm{M}$ : Evaluation of cat scratch disease cases reported from Turkey between 1996 and 2013 and review of the literature. Cent Eur J Public Health 2015; 23:170-175.

8. Chondrogiannis K, Vezakis A, Derpapas M, Melemeni A, Fragulidis G: Seronegative cat-scratch disease diagnosed by PCR detection of Bartonella henselae DNA in lymph node samples. Brazilian J Infect Dis 2012; 16:96-99.

9. Liston TE, Koehler JE: Granulomatous hepatitis and necrotizing splenitis due to Bartonella henselae in a patient with cancer: Case report and review of hepatosplenic manifestations of bartonella infection. Clin Infect Dis 1996; 22:951-957.

10. Povoski SP, Spigos DG, Marsh WL: An Unusual Case of Cat-Scratch Disease from Bartonella quintana Mimicking Inflammatory Breast Cancer in a 50-YearOld Woman. Breast J 2003; 9:497-500.

11. Yapıcı K., Karahocagil MK., Kösem M., Akdeniz N. YG: Tekrarlayan kedi tırmığı hastalı̆ı: bir olgu sunumu. Tıp Araştırmaları Derg 2010; 8:43-46.

12. Gamblin TC, Nobles-James C, Bradley RA, Katner HP, Dale PS: Cat scratch disease presenting as breast mastitis. Can J Surg 2005; 48:254-255.

13. Lefkowitz M WD: Cat-scratch disease masquerading as a solitary tumor of the breast. Arch Pathol Lab Med 1989; 113:473-5. 